Copyright (C) 2016 by Academic Publishing House Researcher

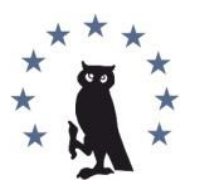

Published in the Russian Federation

European Researcher

Has been issued since 2010.

ISSN 2219-8229

E-ISSN 2224-0136

Vol. 103, Is. 2, pp. 107-118, 2016

DOI: 10.13187/er.2016.103.107

www.erjournal.ru

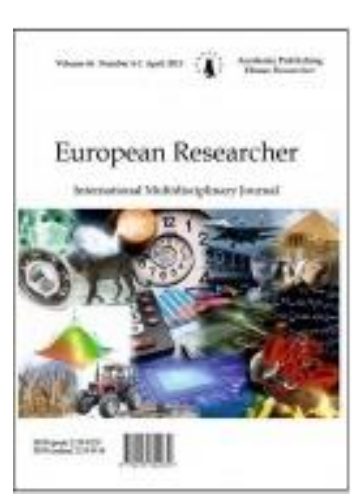

UDC 651.34

\title{
The Determinants of Lifelong Learning
}

\author{
${ }^{1}$ Jasmina Sinanovic \\ ${ }^{2}$ Senad Becirovic
}

\begin{abstract}
${ }^{1}$ International Burch University, Sarajevo, Bosnia and Herzegovina
Department of English Language and Literature

E-mail: jasmina.sinanovic@ibu.edu.ba

${ }^{2}$ International Burch University, Sarajevo, Bosnia and Herzegovina

Department of English Language and Literature

E-mail: senad.becirovic@ibu.edu.ba
\end{abstract}

\begin{abstract}
The aim of this paper is to introduce drivers of lifelong learning and to emphasize its importance in modern life. Developed economies throughout the world are driven more by knowledge and globalization than were economies of even the recent past. European economies of the 20th century were largely driven by manufacturing and the need to industrialize. Filling such economies with functional workers required education systems of similar design, that turned out masses of equally-educated workers in large batches. Increased automation, the widespread introduction of computer technologies and communications, and cheaper transportation have combined to encourage firms to be lean, international, and changing. Computer technologies encouraged sharing of documents, speeded workflow from design to production. Cheaper transportation allowed an increase in internationalization of workforces. These major shifts drove change from industrialized to knowledge-based economies. Paper discusses how two simple English words came together, stayed together, and grew into a powerful term driving new political initiatives, and continue to influence political, economic, social, and even cultural currents. Today's developed societies are rapidly aging, live longer and have fewer children. In order to continue to grow vibrant economies, and to fully enjoy the benefits of these vibrant economies, citizens need to continue to renew knowledge and skills during entire lifetime. As the major technological, economic, and social currents change, so must citizens adapt by never ceasing to learn throughout their lifetimes.
\end{abstract}

Keywords: economics, lifelong learning, lifelong education, knowledge economy, globalisation, change.

\section{Introduction}

The growing recognition of the need lifelong learning is due to the increasing economic and social importance of human capital - our education, skills, competencies, and knowledge. As worldwide economies shift away from economic success for individual human beings, and manufacturing national economies are increasingly dependent on the quality of human capital, 
raising human capital has emerged as a key policy priority, the need for refocus is particularly acute for low-skilled individuals, who are at risk of being left even further behind.

The present day economy is an economy of knowledge, with multicultural character that requires a new and different approach to learning mode, and if we want to be an active part of such economy, we have to be willing to accept the changes, adapt to them quickly, to change existing methods of learning, if we are not to be overrun, we must align to current trends by time and rapid social and economic changes. Younger generations are adapting rapidly to changes. They famously adapt to introductions of new information technology (e.g. smart phones, social media on the Internet, etc.). But all generations need to get more involved to build a successful society. This includes trying new approaches to both learning and teaching. The new emancipatory and creative methods aim at helping a student establish critical faculties as well as creative capacities, while adjusting to complex personalities. The goal of these methods is to match and meet the needs of modern society.

In today's knowledge economy, the value of learning is becoming ever more apparent. As Brian Keeley (2009), writes in Human Capital, How what you know shapes your life (2009): "Whether you're an aged grandmother in Kenya, a 55-year-old manager in Kyoto, or a 25-year-old graduate in Kansas, the economic value of your education is rising." Not only can people no longer afford to stop learning and teaching just because they leave school or university, but they also must cultivate and continue the right type of learning and education. This is because education is, in economic terms, an asset, and like all assets, education requires maintenance. Newly acquired skills can make a difference for individuals, communities, economies, and ultimately, to whole societies. So, as with any asset, it pays to look after one's "human" capital. Parents the world over and in all social classes encourage their children, (their children call such encouragement "nagging"), to study long and hard to achieve high grades, with the expectation that future rewards will follow consequentially from all of the work. Keeley also warns that while human capital can sometimes be dismissed as an irritatingly functional concept, ignoring it has its jeopardies. Amid rising concern about the potential impact on societies of income inequality, the book shows how we need to regard poverty as less an absence of money and more an absence of the resourcesespecially human capital-that are key to social and economic well-being. The present society is the Information Society, an innovative society, a pluralistic society with a multicultural character. It puts pressure on governments and business to increase public spending, but also reduces economic growth. It is also a good opportunity for all of us that the years spent in work and in retirement relive useful. This new society requires that its members change to old life patterns. Members must change and grow to stay functional, and the only way to do this is to learn without stopping - participate in lifelong learning.

\section{What is lifelong learning}

Lifelong learning may be broadly defined as learning that is pursued throughout life: learning that is flexible, diverse and available at different times and in different places. Lifelong learning crosses sectors, promoting learning beyond traditional schooling and throughout adult life (ie postcompulsory education). This definition is based on Delors' (1996) four "pillars" of education for the future.

- Learning to know - mastering learning tools rather than acquisition of structured knowledge.

- Learning to do - equipping people for the types of work needed now and in the future, including innovation and adaptation of learning to future work environments

- Learning to live together, and with others - peacefully resolving conflict, discovering other people and their cultures, fostering community capability, individual competence and capacity, economic resilience, and social inclusion.

- Learning to be - education contributing to a person's complete development, of: mind and body, intelligence, sensitivity, aesthetic appreciation and spirituality.

This is underpinned by "Learning to Learn". Lifelong learning can instil creativity, initiative and responsiveness in people, thereby enabling them to show adaptability in post-industrial society through enhancing skills to: manage uncertainty, communicate across and within cultures, subcultures, families and communities, and negotiate conflicts. The emphasis is on learning to learn 
and the ability to keep learning for a lifetime. Lifelong learning is the idea of systematization of learning at all stages of life (from early childhood to old age) in all its forms (formal, non-formal, informal education, spontaneously, unintentionally and unorganized learning). Learning is a continuous process in which the results and motivation for learning in a certain period of life depend on the knowledge, habits and learning experiences acquired at a younger age. Lifelong learning is defined as "all learning activity undertaken throughout life, with the aim of improving knowledge, skills and competences within a personal, civic, social and/or employment-related perspective". The concept of lifelong learning is linked to the objectives of an economic nature and objectives of encouraging social activities, development of active citizenship and the development of individual potential of individuals.

The European Commission (2001: 9) found that lifelong learning has "Four broad and mutually supporting objectives: personal fulfilment, active citizenship, social inclusion and employability/adaptability". In this regard, lifelong learning has life-wide dimensions that transcend narrow economic and vocational aspects. The European Lifelong Learning Initiative defines lifelong learning as "...a continuously supportive process which stimulates and empowers individuals to acquire all the knowledge, values, skills and understanding they will require throughout their lifetimes and to apply them with confidence, creativity and enjoyment, in all roles circumstances, and environments." (Watson, 2003).

In Sweden, the National Agency for Education has put forward a conceptual framework for both lifelong learning and life-wide learning (Skolverket, 2000). Lifelong learning is seen as a holistic view of education and recognises learning from different environments

Lifelong learning means:

- Acquisition (done by an individual person) and modernization of all kinds of abilities, interests, knowledge and qualifications from the pre-school period until after retirement

- Recognizing (done by societies, institutions, governments, and individual people as students) all forms of learning: formal, non-formal and informal education, as useful and welcome.

The concept of lifelong learning gained prominence in just the last 30 years, as significant and rapid changes have taken place in developed economies and most human societies. Learning does not imply only formal school education; formal education is actually nowadays only basis and foundation for any further learning. Older generations knowledge is firstly earned in schools, then they are employed in certain positions/jobs where they learn the practical part of the work, and by the end of their working life there has been no major changes in their lives outside of work hobbies, interests, etc. (for the most part of them)., and in a way they did not have the need to acquire new knowledge. Today the situation has changed greatly. The success of science, the acceptance of innovation, technological progress, diffusion of information technology and communications improvements becoming integrated into everyday life, and the rapid change and improvement of all require constant retraining and lifelong learning - from preschool until after retirement age. The development of science, innovation, technical and technological progress, information and communication achievements and everyday changes, news and training in these areas require lifelong learning - learning from pre-school until after retirement.

"Education is simply not part of the value system and behaviour pattern of a disturbing number of people" (McGivney, 1990).

\section{A brief history of the term "lifelong learning"}

"I am the wisest man alive, for I know one thing, and that is that I know nothing."

- widely attributed to Socrates, paraphrased from Plato's Apology

Lifelong learning was first discussed by Plato in both Apology and The Republic. But it was Basil Yeaxlee who coined the new term in his book Lifelong Education, published in 1929. In this book, the first of many he would publish on the subject, Yeaxlee focused on learning throughout one's lifetime.

Yeaxlee, in collaboration with Eduard Linderman (1885-1953) focused on adult education. They created a new intellectual foundation for approaching education differently - as an on-going aspect of the daily life of an adult. 
In recent decades, lifelong learning changed from a novel idea into a widely accepted principle dominating the development of many national educational systems. In the 1960's, Europe saw a global crisis of education. The production of new knowledge has accelerated.

The 1970 s were marked by a new approach to education, as economies dominated by manufacturing gave way to the "knowledge economy" International organizations such as UNESCO, OECD and the European Commission began to deal with education, and the concept of "lifelong learning" took shape. The first generation is characterized mainly by Faure's Report for UNESCO Learning to Be (Faure et al., 1972), which propagated a radical humanist and emancipatory perspective on lifelong education. The second generation, from the 1990s onwards, was mostly inspired by documents such as the Delors memorandum on Learning: The Treasure Within' (UNESCO, 1994) and the OECD report on Lifelong Learning for All (1996). 1996 was declared the European Year of Lifelong Learning, when the European Community began with the active promotion of lifelong learning initiative.

"The member states of the European Community have set the target to make Europe the most dynamic and most competitive area of the economy that will be based on knowledge of its citizens, a key strategy of this goal is the availability of life-long learning for all citizens, and free access to learning throughout life." (Croatian Andragogy Society, 2004).

\section{The difference between lifelong learning and lifelong education}

Though different models are produced in relation to the impact of ongoing technological developments on the demands for qualifications (see for instance Gooderham, 1993), the dominant view is that due to changing societies and economies, more qualifications are now and will continue to be needed, leading to an increased focus on lifelong learning. The interest for lifelong term has been at the agenda for many decades, but with different intensity and to some extent also a different focus (Larson, 2005; Rubenson, 2006a). In the 1990's lifelong education and lifelong learning re-entered the political agenda after having been more or less in the dark for about a century. At the same time, adult education went from being a tool for liberating the individual to being a mainly economic tool for increasing the human capital (Larson, 2005).

When the European Council met in Lisbon in 2000, the aim of the meeting was to find a way to "strengthen employment, economic reform and social cohesion as part of a knowledge-based economy" (Lisbon European council: Presidency conclusions, 2000). The Council concluded that lifelong learning is that way to reform and cohesion. Thus, lifelong learning for all is today seen as the way to secure not only the economy, but also social cohesion in European societies.

In spite of different definitions of participation in education and training, most studies agree that participation is unequally distributed among socio-economic groups (Chisholm et al., 2004; Cross, 1981; Darkenwald \& Merriam, 1982; Desjardins et al., in print; Houle, 1961; Larson, 2006; McGivney, 1990; Pont, 2004, Progress towards the Lisbon objectives in education and training, 2006; Tuijnman \& Hellström, 2001). Six years after the decisions made in Lisbon, lifelong learning is still not available to all (Chisholm et al., 2004; Desjardins et al., in print; Larson, 2006, Progress towards the Lisbon objectives in education and training, 2006).

In the English language, very often the concepts of lifelong learning and lifelong education are replaced and looking on translations of the Croatian terms for learning and education, we find these two terms are very different. Learning as a broader concept of education may be accidental, spontaneous and unorganized, and indeed last a lifetime, while lifelong learning can be formal, non-formal and informal learning and is organized.

In typical use of the English language, "lifelong learning" and "lifelong education" are often used interchangeably. But in the Croatian sources which have influenced our region, "learning" and "education" have very different meanings. Learning, as a by-product of education, may be accidental, spontaneous, and unorganized. "Lifelong learning" can include formal and non-formal organized education and training.

No matter what terms are used, schools and universities are not the only places of learning, nor are they even the dominant providers of education. The growing importance of learning throughout one's lifetime, which includes all forms of learning in all circumstances, has shifted roles and locations. 


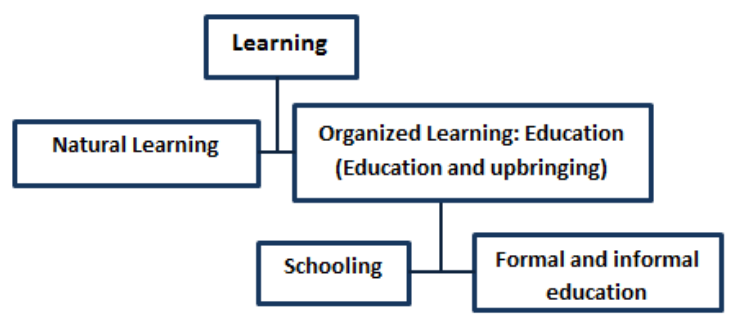

Figure 1: The hierarchical relationship of Learning Types

Natural Learning is simply a conscious acknowledgment that learning can take place in a natural manner without recourse to the institution of school. Natural learning is a postmodern form of education. It holds a position along a continuum with formal classroom learning at one end and "home-schooling" near the other, at a point where links to the institution of school are severed. There are, for example, many home-schooling families that have recreated the institution of school at home. This is not natural learning. Natural learning requires the minimization of the form and function of school.

But isn't all learning natural? Learning is not natural when it consists solely of adults imposing their ideas of the learning needed on children and young people. Adults find it very difficult not to impose their ideas on children. School is an institutionalised and standardised method for adults to impose on children their ideas of what is important to learn and how to learn. The parents, will support their children in their own learning by providing a rich and stimulating environment in which to learn, making available resources for learning, assisting their children to learn when requested to do so, and providing feedback and encouragement to learn. Truly natural learning will be the result of the child's own development and own motivations. This is the way children learn to walk and talk. It can also be the way that they learn to read, write, and are transformed over time into a confident and independent learner. Natural learning can and does work. However, it will be difficult at times. You will need to be ready to defend your decision, because there will be doubters. You will doubt that you are doing the right thing yourself at times, and at other times you will be absolutely sure that you had made the right decision.

The lifelong dimension is relatively non-problematic, as it simply comprises what an individual learns throughout life. It is widely accepted that as knowledge and skills become obsolete, individuals must continually update their competencies in a process of continuing education. Formal education is an important part of lifelong learning. It can provide a strong foundation in general subjects and a robust environment for developing skills used in building a decent life. This key factor often sets the course of lifelong learning, encourages an appreciation for learning from multiple sources. A review of the literature of the last 30 years reveals three main approaches to formal, non-formal, and informal education. Each of these approaches has something to say about the nature of formal education - and each brings out different aspects of the phenomenon. What derives from an administrative or institutional concern and includes a middle form - non-formal education, is the most common way of contrasting informal and formal education. In the late 1960 s there was an emerging analysis of what was seen as a 'world educational crisis' (Coombs 1968). There was concern about unsuitable curricula; a realization that educational growth and economic growth were not necessarily aligned, and that jobs did not emerge directly as a result of educational inputs. Many countries were finding it politically and economically difficult to pay for the expansion of formal education.

The conclusion was that formal educational systems had adapted too slowly to the rapid socio-economic changes around them and that they were held back not only by their own conservatism, but also by the inertia of societies themselves. It was from this point of departure that planners and economists in the World Bank began to make a distinction between informal, non-formal and formal education. (Fordham, 1993). At around the same time there were moves in UNESCO toward lifelong education and notions of "the learning society" which culminated in Learning to $\mathrm{Be}$ ('The Faure Report', UNESCO 1972). Lifelong learning was to be the 'master concept' that should shape educational systems. What emerged was the influential tripartite 
categorization of learning systems. It's best known statement comes from the work of Coombs with Prosser and Ahmed (1974).

Formal education: the hierarchically structured, chronologically graded 'education system', running from primary school through the university and including, in addition to general academic studies, a variety of specialized programs and institutions for full-time technical and professional training.

Informal education: the truly lifelong process whereby every individual acquires attitudes, values, skills and knowledge from daily experience and the educative influences and resources in his or her environment - from family and neighbors, from work and play, from the market place, the library and the mass media.

Non-formal education: any organized educational activity outside the established formal system - whether operating separately or as an important feature of some broader activity - that is intended to serve identifiable learning clienteles and learning objectives.

When we look at usage within discussions of primary schooling, the most consistent form by the late 1980s was the noun "informality", rather than the adjective "informal" (Jeffs \& Smith, 1990). Thus, instead of informal education, it was possible to examine informality in pedagogy, in curriculum, in organization, in evaluation and in personal style (Blyth 1988). What was being examined here was a tendency. To talk of informality in education was to indicate significant elements of flexibility and openness.

\section{Benefits of lifelong learning}

The life-cycle system of education is a basic prerequisite of growth and development. It becomes necessary at a time of rapid changes in the required skills and knowledge. The education system must be adapted and be able to offer opportunities for retraining and upgrading.

1. Lifelong learning enables use of teaching and learning methods tailored to the specific interests of the multicultural societies.

2. Educational system of lifelong learning is focused on the user. The individual becomes an active participant in his or her educational process, which contributes to the use of information and communication technologies.

3. The role of the teacher changes because many more students are separated by space and time; instructors and trainers become leaders, mentors and mediators.

4. Motivation and variety of learning opportunities are prerequisites for successful lifelong learning. It is essential to raise the demand for education, and therefore offer.

5. Lifelong education increases employability of learners.

\section{The knowledge society}

In 1969 the concept of the expression "knowledge society" is used for the first time. A "knowledge society" is one in which the acquisition, creation and application of knowledge predominates. Knowledge is usually accessible to all. Such societies are found to strengthen the prosperity of their host countries and contribute to the welfare of all citizens. Knowledge, innovation and creativity are becoming accepted, gaining recognition as a public good, and are developing into major creative forces.

A complete knowledge society is one that also creates laws and regulations which provide conditions that foster the growth these characteristics and forces.

The knowledge society is a society that is developing thanks to its variety and ability. "In the knowledge society, access to opportunities to acquire the necessary knowledge, skills and competencies is essential for social progress and work" Keeley, 2007, p.19

Knowledge-based society in what is now called the "Information Age" differ from older knowledge societies.

These are the particular features of knowledge societies:

- Freedom of opinion and expression

- The right to education

- The right to freely participate in the cultural life of the community

- Knowledge-based society

- Knowledge workers 
- Information Age

- Developed countries, (and underdeveloped countries).

- Asset

- People

- Citizens

In the developed countries, knowledge is the main development resource, and such societies are called knowledge societies.

"Knowledge is considered as good that is accessible to all with a view to the general wellbeing, and the knowledge society refers to the enlightened society of free and educated people where their knowledge critically examines and argues. However, the present situation in quite a few countries in the world speaks to the fact that the availability and quality of education are not sufficient criteria for the existence of a knowledge society.” Mikelic Preradović, 2009, p.1

The knowledge society needs the support of not only formal education, but the acquisition of competences which enable people to actively participate in society and direct their own lifelong learning.

"The main objective of the knowledge society must be the founding of the society on the creation of new, and application of existing knowledge, and the quality of education must be measured by usability of learned knowledge, skills and attitudes necessary for successful work in difficult conditions of developed society." Mikelic Preradović, 2009, p.154.

\section{Importance and/or advantages of lifelong learning - europeans and eurobarometer research}

The European Commission for Education and Culture, in cooperation with CEDEFOP (European Centre for the Development of Vocational Training) conducted a study in 2003 on lifelong learning called Eurobarometer, to compile the opinions and experiences of lifelong learning of European citizens. The study was conducted on a broad sample of 18277 respondents aged 15 and over from all the countries of the European Community, Norway and Iceland. Eurobarometer reported these key trends: The majority of citizens believe that lifelong learning is important and beneficial to both the individual and community; Necessary to people of all ages. $45 \%$ feel that it is meant for those who were not successful in school, indicating the need to inform citizens about the fact that lifelong learning is relevant for each and every individual at all stages of their life; Citizens believe that the most important skills for Europe are reading and writing, math, general knowledge, computer and Internet skills, knowledge of foreign languages, and finally social skills. Social skills include self-expression, collaboration, problem solving, and organization, etc.; Citizens of Nordic countries possess a far wider range of knowledge and skills compared to citizens of other European countries, especially Southern European countries; Citizens learn best in an informal setting (through television, part time activities, hobbies, socializing and conversations, libraries, and travel); Mostly interested in the education and training of people with a higher education level, and social and personal motives are stronger than their professional, $14 \%$ of respondents never to re-educate; The most important barriers to lifelong learning are lack of time due to family and work commitments: home responsibilities, transportation problems, lack of childcare. Darkenwald and Merriam (1982) also cite institutional and situational barriers but divide the dispositional barriers into psychological obstacles (beliefs, values and perception about education or about oneself as a learner).

\section{International programs dealing with lifelong learning}

The Lifelong Learning Programme (LLP) was designed to enable people, at any stage of their life, to take part in stimulating learning experiences, as well as developing education and training across Europe.

Leonardo da Vinci is part of the European education and training programme "Life-long Learning" and focuses on vocational education and training, other than at tertiary level. It addresses both the learning and teaching needs in the sector, and is therefore aimed at all parties involved, namely trainees in vocational education, teachers and trainers, institutions and educational bodies, enterprises, associations, social partners and bodies relating to either lifelong learning or the labour market. Year after year, Leonardo da Vinci projects develop a multitude of 
innovative education and training products featuring tailored solutions for direct use in companies and at education and training institutions. Leonardo Da Vinci program, which operated from 1995, was created from the need to prepare Europeans to enter the labour market. The goal of this program is to help people improve their skills throughout life. Programs are open in 31 European countries.

The Socrates program is another international program that deals with lifelong learning. The program includes about 30 European countries. The main objective of this program is to build a Europe of knowledge and thus provide a better response to the major business changes occurring in this century. This program also promotes mobility and innovation.

Lifelong Learning Program (Lifelong Learning Programme - LLP) replaces the Socrates, Leonardo da Vinci and eLearning programs, which expired at the end of 2006. (McGowan and Phinnemore (2015) A Dictionary of the European Union, p 441)

The Lifelong Learning Programme (LLP) program of the European Union (EU) aimed education and professional training at all levels. The term lifelong learning encompasses all activities related to lifelong learning, with the aim of improving knowledge, skills and abilities. The program covers the period from 2007 to 2013 and for its implementation during that period at European level, 6.9 billion euros was allocated, making it the largest European program in the field of education. The program aims to contribute to the development of Europe as an advanced knowledge society with sustainable economic development, greater social cohesion and increasing of the number of quality jobs for its citizens. In order to achieve these objectives, the program encourages the exchange and cooperation between educational institutions, individual mobility of students and education professionals, as well as training in vocational areas, which is also preparing students for a successful participation in the European labour market.

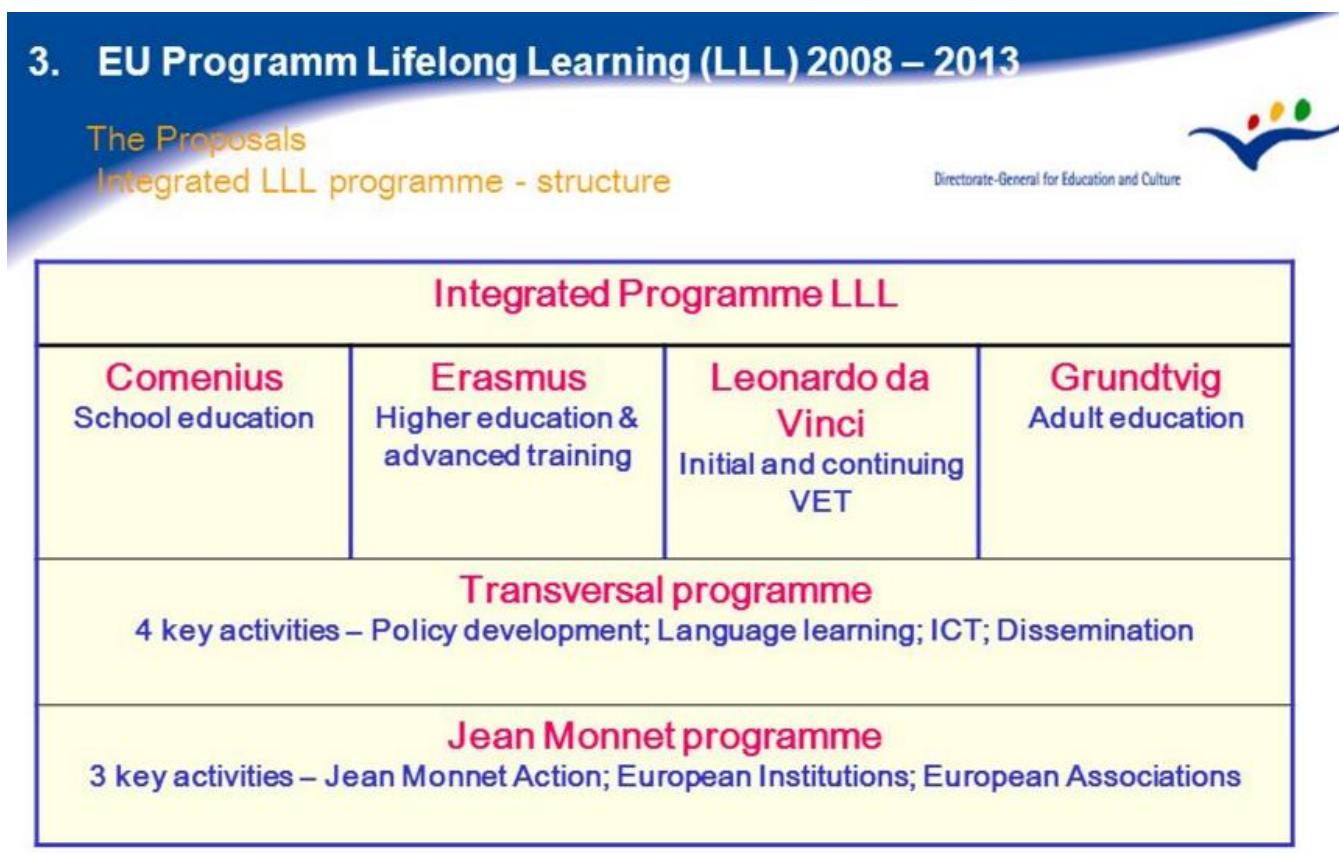

Figure 2: The structure of the program for lifelong learning

The LLP consists of four sectorial sub-programs:

1. Comenius (pre-school and school education),

2. Erasmus (higher education),

3. Leonardo da Vinci (vocational education and training),

4. Grundtvig (adult education)

There are two complementary programs:

The first is Transversal Programme (cooperation and innovation in lifelong learning within the European Union, foreign language learning, the development of innovative information and communication technologies, dissemination and exploitation of the program). The second program is Jean Monnet (support to institutions dealing with European integration). 


\section{Conclusion}

In this transition to a post-industrial society into a truly new epoch, life and work in society will fundamentally change. Learning must and will change as well. Due to intensive scientific, technological and socio-economic changes and changes in work, social and family relationships, it must be necessary to continuously monitor these changes, and actively participate learning to adjust in the new society. One must constantly learn and improve in order to keep up with changes in environment, to meet personal needs and to explore interests.

The knowledge gained as children and young people will not be on the forefront of discovery for long. Integrating continuous learning is an important part of lifelong learning. So too are acquiring new knowledge, skills, abilities and qualities, to develop human capital that enables not just the development of their own, but also the social and economic well-being. New knowledge and learning throughout life helps mingling in a world of constant change, understanding of these changes and in changing society, but also shaping all of us in accordance with these changes. Lifelong learning must be made available to and in all generations, to ensure equal rights to an active and high quality life. "It is certain, however, that older people help in understanding of life and the constant changes that occur in the world and everyday life. Making people part of these changes, rather than passive observers puts them on an equal footing with other generations living in the "learning society".

Motivation and variety of learning opportunities are a prerequisite for successful learning. Lifelong learning must be approached by all participants from all ages and from any aspect, such as: Individual desire and motivation for activity; Employers investing in the education and training of personnel companies; Government organizing and implementing various programs and measures; Government incentives to open adult education institutions. Dedicate yourself to continuous education as knowledge is the primary source of value in our world today. As we enter into the 21st century, the information age, ability to expand our mind, to strive for continuous education are all critical to our success. By dedicating ourselves to lifelong learning, which is the key to breaking through barriers to success that may be in front of us, we devote our lives to working for a better tomorrow.

To summarize, lifelong learners must become effective teachers and self-teachers. Professors and administrators involved with formal education must adapt as well. One of the most practical approaches is to force students out of their comfort zones, involving them in problem-solving and experiential learning programs with their colleagues and students. Where there is a strong and dedicated learning culture present at the institution their supporters, there will also be successful learning for everyone. Although the main benefit of lifelong learning is objectively learning measurable new skills, which was the outward goal, there are personal and professional reasons for continued education and self-directed learning. Self-motivated learners have more motivation for everyday activities, develop mental and cognitive skills, add fun to their lives and daily activities and make new friends, while professionals create opportunities for further employment.

Striving to continually better oneself can be a goal in itself, without a definite endpoint and without motivation to trade the skills for some compensation. These learning goals are not obligations or job requirements, but life goals attracting the enthusiasm and devotion of individuals for their own sake. These, too, are vital and legitimate goals of lifelong learning.

\section{References}

1. Bélanger, P., \& Valdivielso, S. (Eds.). (1997). The emergence of learning societies: Who participates in adult learning? Hamburg: UNESCO Institute for Education.

2. $\quad$ Blyth, A. (ed.) (1988) Informal Primary Education Today, Lewes: Falmer Press.

3. Brockettt, R.G., and Hiemstra, R. (1991). Self-direction in adult learning perspective on theory, research and practice. New York: Routledge.

4. Cheren, A. (1983). The concept of autonomy: A philosophical discussion. Adult Education Quarterly, 34, 38-47.

5. Chisholm, L., Larson, A., \& Mosseux, A.-F. (2004). Lifelong learning: Citizens' views in close-up. Findings from a dedicated Eurobarometer survey. Luxembourg: Office for Official Publications of the European Communities.

6. Christensen, L., Dupont, S., Gale, T., \& Hansen, L. (1997). Travle halvgamle mænd i uddannelsessamfundet. København: Undervisningsministeriet. 
7. Coombs, P. (1968) The World Educational Crisis, New York, Oxford University Press.

8. Coombs, P. with Ahmed, M. (1974) Attacking Rural Poverty, Baltimore: The John Hopkins University Press.

9. Cross, K.P. (1979). Adult Learner: Characteristics, Needs and Interests. In R.E. Peterson and Associates (eds), Lifelong Learning In America. San Francisco: Jossey-Bass.

10. Cross, K. P. (1981). Adults as learners. San Francisco: Jossey-Bass.

11. Darkenwald, G. G., \& Merriam, S. B. (1982). Adult education: Foundations of practice. New York: Harper \& Row Publishers.

12. Darlington, R.B. (1997). Factor analysis. Retrieved August, 2006, from http://www.psych.cornell.edu/Darlington/factor.htm

13. Delors, J. (1996) Learning: The treasure within Report to UNESCO of the International Commission on Education for the Twenty-first Century, UNESCO

14. Desjardins, R., Rubenson, K., \& Milana, M. (in print). Unequal changes to participate in adult learning. International perspectives. Paris: UNESCO.

15. European Commission (2001) Making a European area of lifelong learning a reality, Brussels, COM (2001) 428final

16. European Parliament (2000). Lisbon European Council 23-24 March 2000. Presidency Conclusions. Brussels: European Parliament.

17. Faure, E., Herrera, F., Kaddoura, A.-R., Lopes, H., Petrovsky, A. V., Rahnema, M. \& Champion Ward, F. (1972). Learning to Be: The World of Education Today and Tomorrow. Paris: UNESCO.

18. Fordham, P. E. (1993) 'Informal, non-formal and formal education programmes' in YMCA George Williams College ICE301 Lifelong Learning Unit 2, London: YMCA George Williams College.

19. Fourth, E. (1999), Educology, Zagreb: Znamen

20. Gooderham, P. (1993). Etterutdanning i lys av endringer i arbeidsmarkedet og utddanningssystemet: Noen politiske og utdanningssociologiske utfordringer. Sosiologisk Tidsskrift(4), 295-309.

21. Jeffs, T. and Smith, M. K. (1999a) 'Informal education and health promotion', in E. R. Perkins, I. Simnett and L. Wright (eds.) Evidence-Based Health Promotion, London: John Wiley.

22. Johnstone, J.W.C., and Rivera, R.J. (1965). Volunteers for Learning. Chicago: Aldine.

23. Keeley, BRIAN, (2009), OECD Insights Human Capital How what you know shapes your life: How what you know shapes your life, isbn 9264029087, 9789264029088

24. Keegan, D. (1999). Distance Education Models at the Dawn of the Third Millenium. Proceedings, 13th Annual Conference Asian Association of Open Universities, 14-17th October 1999, Beijing.

25. Klapan, A. and Matijevic, M. (Eds.), (2004), Adult Education the key to the 21st century, Proceedings drugemeđunarodne conference, Zagreb: Croatian Andragogy Society

26. Knowles, M.S (1975). Self-directed Learning: A Guide for Learners and Teachers. Chicago: Follet Publishing Company.

27. Knowles, M.S (1980). The Modern Practice of Adult Education: From Pedagogy to Andragogy. Chicago: Association Press.

28. Larson, A. (2004). Psykosociale forhold i arbejdslivet og kortuddannede/ufaglærtes interesse for uddannelse. Ph.D. Thesis. Copenhagen: Danish University of Education.

29. Larson, A. (2005). Lifelong learning at the international agenda - and its implementation in a Danish context. In S. Kiefer \& T. Peterseil (Eds.), Analysis of educational policies in a comparative perspective (pp. 123-140). Linz: Trauner Verlag.

30. Larson, A. (2006). Participation and non-participation in adult education and training. In S. Ehlers (Ed.), Milestones - towards lifelong learning systems (pp. 47-61). Copenhagen: Danish University of Education Press.

31. Latour, B. (2004). Why Has Critique Run Out of Steam? From Matters of Fact to Matters of Concern. Critical Inquiry, 30(2), 225-248.

32. Lifelong learning: Citizens view. (2003). Thessaloniki: CEDEFOP.

33. Lisbon European council: Presidency conclusions. (2000). Lisbon: Commission of European Communities. 
34. McGivney, V. (1990). Education's for other people. Access to education for nonparticipant adults. Leicester: National Institute of Adult Continuing Education (NIACE).

35. McGivney, V. (1999). Excluded men. Men who are missing from education and training. Leicester: National Institute of Adult Continuing Education (NIACE).

36. Mikelic Preradović, N. (2009), Learning for a knowledge-based society, Zagreb: Department of Information Studies

37. Moss, G. (1987). The Trainers Handbook. Singapore: Singapore Institute of Management.

38. OECD (1996). Lifelong Learning for All. Paris: Organization for Economic Co-operation and Development.

39. Pivac, J. (2000), an innovative school in the Knowledge Society, Zagreb: Croatian Pedagogical - Literary Society

40. Pont, B. (2004). Improving access to and participation in adult learning in OECD countries. European Journal of Education, 39(1), 31-45.

41. Progress towards the Lisbon objectives in education and training. Report based on indicators and benchmarks. (2006). Brussels: Commision of the European Union.

42. Putnam, R. D. (2000). Bowling Alone. New York: Simon \& Shuster.

43. Rubenson, K. (1976). Rekrytering till vuxenutbildning. En forskningsstrategi. Stockholm: Lärerhögskolan i Stockholm, Pedagogiske Institutionen.

44. Rubenson, K. (2006a). Constructing the lifelong learning paradigm: Competing visions from the OECD and UNESCO. In S. Ehlers (Ed.), Milestones towards lifelong learning systems (pp. 151-170). Copenhagen: Danish University of Education Press.

45. Skolverket (2000) Lifelong Learning and Lifewide Learning, Stockholm, The National Agency for Education

46. Smith, M. K. (2002) 'Informal, non-formal and formal education: a brief overview of different approaches', the encyclopedia of informal education, http://www.infed.org/ foundations/informal_nonformal.htm

47. Tuijnman, A., \& Hellström, Z. (Eds.). (2001). Currious minds. Nordic adult education compared. København: Nordic Council of Ministers.

48. UNESCO (1972) Learning to Be (prepared by Faure, E. et al), Paris: UNESCO.

49. UNESCO (1994). Learning: The Treasure Within. Report to UNESCO of the International Commission on Education for the 21st Century. Paris: UNESCO Publications.

50. UNESCO (1998). Final Report. Fifth International Conference on Adult Education. Hamburg: 14-18 July 1997. Paris: UNESCO Publications.

51. Watson, L. (2003) Lifelong Learning in Australia, Canberra, Department of Education, Science and Training.

УДК 651.34

\title{
Детерминанты непрерывного обучения
}

\author{
1 Джасмина Синанович \\ ${ }^{2}$ Сенад Бекирович
}

\author{
${ }^{1}$ Международный университет Берч, Сараево, Босния и Герцеговина \\ Кафедра английского языка и литературы \\ E-mail: jasmina.sinanovic@ibu.edu.ba \\ ${ }^{2}$ Международный университет Берч, Сараево, Босния и Герцеговина \\ Кафедра английского языка и литературы \\ E-mail: senad.becirovic@ibu.edu.ba
}

Аннотация. Целью данной работы является ознакомление с движущими силами непрерывного обучения и подчеркивание его важности в современной жизни. Развитые страны во всем мире управляются в большей степени за счет знаний и глобализации экономики. Европейские страны в XX века были во многом ориентированы на производство 
и необходимость индустриализации. Сегодня в развитых странах население стремительно стареет, продолжительность жизни увеличилась, количество детей в семьях уменьшилось. В целях дальнейшего развития процветающей экономики, и возможностям пользования в полной мере преимуществами развитой экономики, гражданам необходимо продолжать обновлять знания и навыки в течение всей жизни. В качестве основных изменений под которые должны адаптироваться граждане, никогда не переставая учиться на протяжении всей своей жизни, можно отметить технологические, экономические и социальные течения.

Ключевые слова: экономика, непрерывное образование, экономика знаний, глобализация, изменение. 